\title{
English Law's Epistemology of Expert Testimony
}

\author{
TONY WARD*
}

The decision whether to believe an expert witness raises difficult epistemological and ethical questions for a lay juror or judge. This article examines the English courts' approach to these questions in the light of a series of cases which endorse the test of admissibility formulated in the Australian case of $\mathrm{R} v$. Bonython. It argues that, if interpreted more rigorously than it generally has been to date, Bonython could provide the framework for an approach which avoids the pitfalls of either a 'scientistic' or a 'constructivist' epistemology of expert testimony. Such an approach needs to distinguish between different types of expertise and the differing degrees of deference that they call for on the part of a lay fact-finder.

What is 'a body of knowledge or experience which is sufficiently organized or recognized to be accepted as ... reliable' by a court? That is one of the criteria, formulated by King CJ of South Australia in $R \mathrm{v}$. Bonython, ${ }^{1}$ which appear increasingly firmly established as the test for admissibility of expert evidence in English law. ${ }^{2}$ According to one school of thought, reflected to some extent in United States Supreme Court decisions, ${ }^{3}$ the answer should be that whether a form of expertise (even, arguably, one that does not claim

\section{* Law School, University of Hull, Hull HU6 7RX, England}

Thanks to Luca Malatesti and Chris Slobogin for their many helpful suggestions on epistemology and United States law respectively, to Phil Bielby, Massimo la Torre, Joelle Moreno, Peter Paulden, and Suzanne Uniacke for their comments on various drafts, to Andrew Roberts for sharing his forthcoming work, and to the anonymous referees for their detailed and constructive comments.

$1 R$ v. Bonython (1984) 38 SASR 45, 47.

2 See $R$ v. Luttrell [2004] 2 Cr. App. R. 31, paras. 32-3; $R$ v. Harris (2005) 85 BMLR 75, para. 270, and the other cases cited below. The influence of Bonython owes much to its extensive quotation in successive editions of Archbold, for example, Archbold 2004 para. 10.65.

3 Daubert v. Merrell Dow Pharmaceuticals 509 US 579 (1993); Kumho Tire Co. v. Carmichael 526 U.S. 137 (1999). 
to be scientific) $)^{4}$ should be accepted as reliable depends upon how closely its methods and theories approximate to the desiderata of scientific method. ${ }^{5}$ From another perspective, 'reliability' is socially constructed through the deployment of various rhetorical strategies; ${ }^{6}$ courts can make the construction and deconstruction of expertise publicly visible, but should not 'be seduced into mistaking the play for objective reality. ${ }^{7}$

Neither of these perspectives (which we may label respectively 'scientistic' and 'constructivist') quite gets to grips with the question, which is about what it is rational for judges and juries to accept from their perspective as non-experts. The scientistic perspective refuses to distinguish between the rationality of science and that of lay evaluation of expertise, ${ }^{8}$ while the constructivists appear reluctant to address normative questions of rationality at all.

The analysis of the specific form of rationality that our question concerns is an aspect of the epistemology of testimony: that is, how one person can acquire knowledge from the statements of another. ${ }^{9}$ The evaluation of legal testimony, however, falls in the area of overlap between epistemological and ethical appraisal of belief. ${ }^{10}$ The question to be addressed is not 'how can legal actors acquire knowledge?' but, rather, 'what cognitive commitments can legal actors legitimately make in the course of their public duties?' Because of this ethical dimension, the evaluation of courtroom testimony needs to meet more stringent epistemic requirements than may be appropriate in many everyday situations.

The article first elaborates on this ethical/epistemological approach and then attempts to elucidate and evaluate the approach implicit in English law,

4 See D.L. Faigman, 'Expert Evidence in Flatland: The Geometry of a World Without Scientific Culture' (2003) Seton Hall Law Rev. 255, fn. 11.

5 See, for example, B. Black, F.J. Ayala, and C. Saffran-Brinks, 'Science and the Law in the Wake of Daubert: a New Search for Scientific Knowledge' (1994) 72 Texas Law Rev. 715; D.L. Faigman, E. Porter, and M.J. Saks, 'Check Your Crystal Ball at the Courthouse Door, Please: Exploring the Past, Understanding the Present, and Worrying about the Future of Scientific Evidence' (1994) 15 Cardozo Law Rev. 1799; E. Beecher-Monas, 'The Heuristics of Intellectual Due Process: A Primer for Triers of Science' (2000) 75 NYU Law Rev. 1563.

6 See, for example, C.A.G. Jones, Expert Witnesses (1994); S. Jasanoff, Science at the Bar (1995); G. Edmond, 'Judicial Representations of Scientific Evidence' (2000) 63 Modern Law Rev. 216.

7 S. Jasanoff, 'Expert Games in Silicone Gel Breast Implant Litigation' in Science in Court, eds. M. Freeman and H. Reece (1998) 104.

8 See B. Leiter, 'The Epistemology of Admissibility: Why Even Good Philosophy of Science would not make for Good Philosophy of Evidence' [1997] Brigham Young University Law Rev. 803.

9 See C.A.J. Coady, Testimony: A Philosophical Study (1992) ch. 16; A. Goldman, 'Experts: Which Ones Should You Trust?' (2001) 63 Philosophy and Phenomenological Research 85; E. Fricker, 'Testimony and Epistemic Autonomy' in The Epistemology of Testimony, eds. J. Lackey and E. Sosa (2006).

10 See S. Haack “"The Ethics of Belief” Reconsidered' in Knowledge, Truth and Duty, ed. M. Steup (2001). 
and more particularly, in the recent appellate decisions which have adopted the Bonython test. I shall argue that, if interpreted with a degree of rigour often lacking in the English judgments, Bonython does afford an ethically and epistemologically defensible basis for the acceptance of expert evidence. The article focuses primarily on jury trials and thus, in the English context, on criminal cases.

\section{LAW AND EPISTEMOLOGY}

\section{Internalism and transparency}

The ethical dimension of legal epistemology is crucial to the choice between internalist and externalist perspectives in epistemology. Internalism is the view that a true belief cannot count as knowledge unless it is justified by reasons accessible to the person whose belief it is. Externalism is the view that a true belief counts as knowledge if it is arrived at by a reliable process, whether or not the believer knows the process to be reliable. What Michael Pardo, who has recently examined the legal implications of this debate in depth, writes of United States federal law is also true of English criminal law: it 'adopts a rather systematic form of weak internalism'. ${ }^{11}$ That is, it regards a jury or magistrates as entitled to make a cognitive commitment ${ }^{12}$ (such as finding a charge or defence proved to the relevant standard) if it had access to reasons that could justify that commitment, but does not require that the jury ${ }^{13}$ actually cite those reasons. This is 'prima facie a perfectly acceptable epistemic stance', ${ }^{14}$ but it also reflects an important legal principle. The classic formulation of the principle is J.F. Stephen's:

[The public's] reasonable demand is, that no one shall be punished unless his guilt be proved on grounds which the bulk of the nation at large can understand. ${ }^{15}$

The reasonableness of this demand is one aspect of the more general principle that, to be morally legitimate, legal decisions must be justified on grounds that could be rationally accepted by those they affect. ${ }^{16}$ Since

11 M.S. Pardo, 'The Field of Evidence and the Field of Knowledge' (2005) 24 Law and Philosophy 321, at 365.

12 On epistemic entitlements and commitments, see R. Brandom, Making it Explicit (1994) 201-6.

13 Magistrates do now give reasons, but these need comprise no more than 'a few simple sentences': $R$ (McGowan) v. Brent Justices [2002] Crim. L.R. 412, 414.

14 Pardo, op. cit., n. 11, p. 366.

15 J.F. Stephen, A General View of the Criminal Law of England (1863) 213. For an argument that Stephen's position can be defended in more democratic terms than his own, see T. Ward, 'Experts, Juries, and Witch-hunts: from Fitzjames Stephen to Angela Cannings' (2004) 31 J. of Law and Society 369.

16 J. Habermas, Between Facts and Norms (1996) 107; T. Ward, 'Two Schools of Legal Idealism: A Positivist Introduction’ (2006) 6(3) Ratio Juris 127. 
criminal courts purport to censure and punish people on behalf of the community at large, the general public is, in a sense, a party to criminal proceedings.

Stephen went on to observe that:

[a]n omniscient and infallible judge who decided by processes unintelligible to the world at large would not give satisfaction, for though his decisions would always be right, no one could check them.

On an externalist account, if the public unquestioningly accepted the judge's verdicts it would acquire knowledge. But unless it could justify its belief in the judge's omniscience, it would not acquire a moral justification for censuring those whom the judge condemned. As Robert Brandom argues, to take someone to be reliable is to endorse that person's inferences 'as premises in one's own inferences (including practical ones)', ${ }^{17}$ and such endorsement can only be justified by reasons that are within one's cognitive grasp. Similarly, a judge's or jury's endorsement of the evidence of an expert as a premise in practical reasoning about the use of coercive power must be justified by reasons within the judge's or jury's own grasp. ${ }^{18}$ Given its practical character, legal epistemology must be internalist.

The criminal law adopts only a 'weak' form of internalism because of the impracticality of requiring detailed reasons from a jury, and perhaps also because spelling out the reasons for verdicts could damage their legitimacy as definitive statements about past events. ${ }^{19}$ Provided the jury was presented with reasons that could justify its conclusions, its verdict will generally be regarded as 'safe' by the Court of Appeal without any inquiry into whether those reasons actually motivated the jury's verdict. English law does, however, require the trial judge to articulate in some detail the reasons that are capable of justifying the verdicts open to the jury. This provides the public (and the Court of Appeal) with an assurance that the jury is entitled to make the cognitive and moral commitment involved in convicting the defendant.

Somewhat different considerations apply in civil cases, where as Stephen remarked, the parties may 'prefer the decision of an expert' and 'the public have, generally speaking, no interest in such decisions', or at least none comparable to their interest in criminal punishment. ${ }^{20}$ Corrective justice is concerned not with the reasons that the community at large has to censure particular persons but with the reasons that one person has to make good the harm caused to another. ${ }^{21}$ In order to be rationally acceptable to the parties, a

17 R. Brandom, Articulating Reasons (2000) 120. Pardo, op. cit., n. 11, draws heavily on Brandom's analysis.

18 S. Brewer, 'Scientific Expert Testimony and Intellectual Due Process' (1998) 107 Yale Law J. 1535.

19 C. Nesson, 'The Evidence or the Event? On Judicial Proof and the Acceptability of Verdicts' (1985) 98 Harvard Law Rev. 1357.

20 Stephen, op. cit., n. 15, p. 218.

21 J. Coleman, 'The Practice of Corrective Justice' (1995) 37 Arizona Law Rev. 15. 
judgment must be based on reasons that can be understood and accepted by parties who may have very different levels of technical expertise (for example, drug companies and those allegedly injured by their products). This seems more likely to be achieved by the reasoned decision of a judge than the unreasoned verdict of a jury. The judge must be able to justify the conclusions reached - a strongly internalist epistemological requirement but in some disputes of a highly technical nature (for example, some patent disputes) it may be legitimate that the judge gives reasons based on special expertise and cognitively inaccessible to the public at large. Where matters of public policy are at stake, however:

[r] eview by generalist judges symbolises [the] nation's continued adherence to the principle that governmental actions, however arcane or esoteric, must be explained in terms that are comprehensible to non-expert audiences. ${ }^{22}$

\section{Underdetermination}

A second important feature of criminal law's epistemology is its recognition that although fact-finding is a rational process, the results are often undetermined by reason. As Raz points out:

The manifestations of underdetermination by reasons are widespread and familiar. For example, two people hear the same testimony and one believes it while the other does not ... [Often] both have to admit that the other is not irrational ... Common as underdetermination by reason is it has not received adequate attention in epistemology. ${ }^{23}$

A good example of the neglect of underdetermination in epistemology is Alvin Goldman's assumption that whenever a jury and a 'shadow jury', or a jury and a judge, disagree about the verdict in a trial, one of them must be mistaken. ${ }^{24}$ Acquittal does not signify a belief in innocence, but absence of the requisite level of belief in guilt. Two fact-finders can reasonably arrive at different degrees of belief without either being mistaken.

The House of Lords recognized this point when it unanimously reaffirmed in $R \mathrm{v}$. Wang $^{25}$ that the judge must withdraw a case from the jury where there is no reasonable basis on which it could convict, but it is never entitled to direct it to convict. Although their Lordships partly justified this asymmetry by reference to the jury's power to return a 'perverse' verdict, ${ }^{26}$ the ground for quashing the appellant's conviction was that, however thin his defence might have appeared to the judge, it might 'well have given rise to nuances ... not recognised by the judicial mind. These were pre-eminently

22 Jasanoff, op. cit., n. 6, p. 215.

23 J. Raz, Engaging Reason (1999) 138-9. See, also, Ward, op. cit, n. 15.

24 A. Goldman, Knowledge in a Social World (1999) 312.

$25 R$ v. Wang [2005] 1 W.L.R. 661.

26 id., paras. 16-17, rejecting the trenchant criticism of 'perverse' verdicts by Auld LJ, Criminal Courts Review (2001) 173-6 (ch. 5, paras. 90-108). 
matters for evaluation by the jury. ${ }^{27}$ Between the Galbraith $^{28}$ threshold for leaving a case to the jury and the point where an acquittal could only be considered perverse, there is a wide spectrum of cases where a reasonable jury might or might not be sure of guilt: where their verdict is underdetermined by reason.

The importance of underdetermination in the context of expert evidence is that the expert does not need to adduce reasons that would compel any rational person to accept her conclusions; she need only produce reasons that could persuade a rational juror that her conclusions are sufficiently credible, taken with other relevant evidence, to satisfy the relevant standard of proof. The jury is left (as Stephen argued) with what is essentially a practical decision: given such reasons as are cognitively accessible to the jurors (and to the community at large), are they justified in placing the degree of trust in the expert testimony that would lead them to return a particular verdict?

\section{Inferentialism and the Bonython test}

We now come to another major divide in epistemology: that between 'inferentialist' and 'credulist' views of testimony. Credulists assert, and inferentialists deny, that one can 'gain a justified belief in a proposition simply on the basis of hearing someone assert that proposition'. ${ }^{29}$ For inferentialists, justification requires some basis from which it can be inferred that the testimony relied upon is probably true; for credulists, believing what one is told is a justified 'default position, ${ }^{30}$ in the absence of specific grounds for doubt.

Credulism is untenable in the legal context, even if it is plausible elsewhere. ${ }^{31}$ In many situations, it may be (as John McDowell puts it) a doxastically responsible policy to take testimony (including expert testimony) as presumptively true. ${ }^{32}$ Given the momentous practical questions at issue in legal proceedings, however, a higher degree of epistemic responsibility is required. This is especially true in criminal cases where, as Roberts and Zuckerman argue:

27 id., para. 17

28 (1981) 73 Cr. App. R. 124.

29 See D. Pritchard, 'Testimony' in The Trial on Trial, vol. 1, eds. A. Duff, L. Farmer, S. Marshall, and V. Tadros (2004) 101-2.

30 T. Burge, 'Content Preservation' (1993) 102 Philosophical Rev. 457, at 468.

31 Both Pritchard, op. cit., n. 29 and R. Audi, 'The Place of Testimony in the Fabric of Knowledge and Justification' (1997) 34 Am. Philosophical Q. 405, at 406 take this position, though for somewhat different reasons from those advanced here. For a credulist (and externalist) view of the testimony of experts in everyday life, see M.O. Webb, 'Why I Know About as Much as You: A Reply to Hardwig' (1993) 90 J. of Philosophy 260.

32 J. McDowell, 'Knowledge by Hearsay' in Meaning, Knowledge and Reality (1998). 
In order to infer the accused's guilt beyond reasonable doubt the fact-finder has to dismiss every hypothesis that is consistent both with the evidence and with the accused's innocence. The fact-finder must be satisfied, in particular, that the witness is not mistaken ... or deliberately telling lies. ${ }^{33}$

This argument applies only to prosecution evidence on matters where the prosecution bears the burden of proof, but a defence withess who contradicts credible prosecution evidence can hardly be believed uncritically, since there is obviously reason to consider the possibility of deception or mistake. Similarly, to believe testimony 'on the balance of probabilities', one must weigh in the balance the probability that it is false.

A thoroughgoing credulist approach to legal expert testimony would hold that in the absence of evidence to the contrary, courts are entitled to assume (a) that purported experts have the credentials and experience they say they have (an assumption which courts do routinely make, and which is not always sound); ${ }^{34}$ and (b) that anything a qualified expert says within her field is reliable. Although no philosopher advocates such a simple position, ${ }^{35}$ it corresponds quite closely to what Giannelli labels the 'relevancy' approach which formerly held sway in the United States of America and still prevails in some states. ${ }^{36}$ It also resembles the English approach in cases such as $R \mathrm{v}$. $\operatorname{Robb}^{37}$ and - egregiously $-R$ v. Dallagher. ${ }^{38}$

In recent years both United States and English law have moved beyond the relevance approach. In Daubert v. Merrell Dow Pharmaceuticals ${ }^{39}$ (now followed in at least 19 states) ${ }^{40}$ the Supreme Court held that 'the trial judge must ensure that any and all scientific testimony or evidence admitted is not only relevant, but reliable'. ${ }^{41}$ The English Court of Appeal, in a series of cases which will be examined below, has adopted the test proposed by King $\mathrm{CJ}$ of the South Australian Supreme Court in $R$ v. Bonython. King CJ stated

33 P. Roberts and A. Zuckerman, Criminal Evidence (2004) 367.

34 For example, in Luttrell, op. cit., n. 2, the Court of Appeal accepted without question (para. 32) a lipreader's claim to have an Oxford degree, which cross-examination in a subsequent trial exposed as false: "Arlene case lip-reader is dropped for "misleading" court over CV' Scotsman, 28 June 2005.

35 The leading contemporary 'credulist', Coady, op. cit., n. 9, presents a more complex and nuanced view of legal expert testimony, based on a provisional faith in the views of established communities of experts. See text to n. 57 below.

36 P.C. Giannelli, 'Daubert: Interpreting the Federal Rules of Evidence' (1993) 15 Cardozo Law Rev. 1999; P.C. Giannelli, 'Daubert Revisited' (2005) 41(3) Crim. Law B. 5.

$37 R$ v. Robb [1991] 93 Cr. App. R. 161. See D. Ormerod, 'Sounding Out Expert Voice Identification' [2002] Crim. L.R. 771.

$38 R$ v. Dallagher [2003] 1 Cr. App. R. 12. See W.E. O'Brian, 'Court Scrutiny of Expert Evidence: Recent Decisions Highlight the Tensions' (2003) 7 Inernational J. of Evidence \& Proof 172.

39 Daubert, op. cit., n. 3.

40 M.L. Real, 'Application of Daubert and/or Frye in State Courts' (2005), available on Westlaw, SK071 ALI-ABA 503.

41 Daubert, op. cit., n. 3, p. 589. 
that there were two questions that had to be answered before expert evidence was admitted: (i) 'whether the subject matter of the opinion falls within the class of subjects upon which expert testimony is permissible', and (ii) whether the witness had a sufficient knowledge of that subject. The first question could be subdivided into two parts:

(a) whether the subject matter of the opinion is such that a person without instruction or experience in the area of knowledge or human experience would be able to form a sound judgment on the matter without the assistance of witnesses possessing special knowledge or experience in the area, and (b) whether the subject matter of the opinion forms part of a body of knowledge or experience which is sufficiently organized or recognized to be accepted as a reliable body of knowledge or experience, a special acquaintance with which by the witness would render his opinion of assistance to the court. ${ }^{42}$

Limb (a) of the first question is the familiar 'common knowledge' test, ${ }^{43}$ but limb (b) marks a significant departure from the approach of the English courts in cases such as Robb and Dallagher. No longer can juries be invited to place blind trust in any witness who has knowledge or experience of an area in which the jury has insufficient knowledge to make its own judgments. That knowledge or experience must have properties of 'organization' or 'recognition' from which the court can infer that it is reliable.

As an anonymous referee has pointed out, this is not how Bonython is interpreted by the Law Commission of Australia, which cites it as authority for the proposition that South Australian law requires only that the relevant 'field of expertise' be 'generally accepted ${ }^{44}$ as reliable, not that the court determine its reliability for itself. ${ }^{45}$ The Law Commission's view, however, is not supported by the Supreme Court of South Australia's recent decision in $R$ v. Bjordal, ${ }^{46}$ where all three judges emphasized the need for the body of knowledge to be 'sufficiently organised to be accepted as reliable', meaning not only that it was the subject of organized training and procedures, but also that the particular proposition on which an accident reconstruction expert relied should have been empirically tested. It seems clear from Bjordal that

42 Bonython, op. cit., n. 1, pp. 46-7.

$43 R$ v. Turner [1975] Q.B. 834; $R$ v. $X$ [2006] 1 Cr. App. R. 10. For a recent Australian application of this limb of Bonython, see The Queen v. Joyce (NT Sup Ct) [2006] Crim. L.R. 276.

44 Frye v. US 293 F. 1013 (1923) which though not cited, let alone endorsed, in Bonython, seems to have indirectly influenced it: see I. Freckelton, 'Judicial Attitudes Toward Scientific Evidence: The Antipodean Experience’ (1997) UC Davis Law Rev. 1137, at 1196-7.

45 ALRC Discussion Paper 69: Review of the Uniform Evidence Acts (2005) para. 8.36. See, also, A. Roberts and D. Ormerod, 'The Admissibility of Expert Evidence' in Witness Testimony: Psychological, Investigative and Evidential Perspectives, eds. A. Heaton-Armstrong, G. Gudjonsson, E. Shepherd, and D. Wolchover (2006) s. 24.33 .

46 Bjordal (2005) 93 SASR 237 [2006] Crim. L.R. 183. 
South Australian judges are expected to scrutinize the relevant body of knowledge' for themselves in order to determine whether it has properties from which the reliability of the expert's evidence can be inferred.

The endorsement of Bonython is therefore a step in the direction of the House of Commons Science and Technology Committee's recommendation for a 'gatekeeping' test, though the Committee did not discuss Bonython and recommended that the Forensic Science Advisory Committee should formulate a test building on the Daubert model. ${ }^{47}$ Another recent influential report, on the investigation of sudden infant deaths, paraphrases Bonython in its recommendations to judges. ${ }^{48}$

\section{TOO HARD FOR LAY PEOPLE?}

As the Court of Appeal has emphasized, ${ }^{49}$ the Bonython test is a criterion of admissibility, not weight. The judge has only to determine that the evidence has some potential probative value (which outweighs any prejudicial effect); it remains for the jury to decide what weight, if any, to give it. But are lay juries or a scientifically unqualified judge competent to make the kind of inferences that Bonython requires?

Scott Brewer, in what is probably the most sophisticated analysis of expert evidence to date, concludes emphatically that they are not, and the only way to achieve epistemically responsible decision-making about expert evidence is to give the task to judges with both scientific and legal expertise. This, of course, gives rise to the same problem as Stephen's omniscient judge: if lay people are incompetent to decide whether to believe one expert or another, how can they decide whether to believe the judge's verdict? As Brewer acknowledges, '[r]ule by technocrat-kings' raises questions of 'democratic legitimacy'. 50

Brewer arrives at his pessimistic conclusion by considering four possible routes to justified acceptance of an expert's conclusions: ${ }^{51}$ (i) 'substantive second-guessing' (that is, evaluating the expert's reasoning independently); (ii) 'using general cannons of rational evidentiary support' (for example, rejecting evidence that is internally contradictory); (iii) judging the expert's

47 Science and Technology Committee, Seventh Report, Forensic Science on Trial, HC 2004-05, para. 173; Roberts and Ormerod, op. cit., n. 45, s. 24.48. On Daubert (op. cit., n. 3), see pp. 592-3 below.

48 H. Kennedy (chair), Sudden Unexpected Death in Infancy. The report of a working group convened by the Royal College of Pathologists and The Royal College of Paediatrics and Child Health (2004) 6.

$49 R$ v. $G$ [2004] 2 Cr. App. R. 48.

50 Brewer, op. cit., n. 18, p. 1679. For a detailed critique of Brewer's arguments, see A. Golanski, 'Why Legal Scholars get Daubert Wrong: A Contextualist Explanation of Law's Epistemology' (2001) 22 Whittier Law Rev. 653.

51 Brewer, id., pp. 1616-30. 
demeanour; and (iv) relying on credentials. Clearly (i) and (ii) are not applicable to all cases, although they may - with the aid of effective crossexamination - be applicable to a considerable proportion. ${ }^{52}$ Route (iii) is hopelessly naïve given the role of experts in the adversary system. ${ }^{53}$ Route (iv) branches into two: the kind of 'credulist' argument discussed above, which Brewer rightly rejects, and an inferentialist version which requires the layperson to infer inductively from successful dealings with credentialed experts that credentials generally signal reliability. Brewer constructs an elaborate form of the latter variant, but plausibly concludes that most nonexperts will not have had dealings with a sufficient range of experts to warrant any such sweeping generalization. ${ }^{54}$ If Brewer's four routes are really the only options available to the non-expert, the lay judge or jury's predicament appears hopeless in many cases.

If lay judges and juries cannot cope with the evaluation of expert evidence, an alternative solution might be to leave questions of admissibility to something like the 'Registration Committee' proposed by the philosopher Anthony Kenny. ${ }^{55}$ Kenny's proposal is not for a register of individual experts, like that now maintained by the Council for the Registration of Forensic Practitioners (under which the competence of individuals is certified by colleagues from the same discipline), ${ }^{56}$ but rather a register of sciences which would certify that certain disciplines had, in the opinion of experts drawn from other established disciplines, attained the status of a 'mature science'. Methods that were not certified as 'mature sciences' would be excluded.

Kenny's proposal again raises the same problem as Stephen's omniscient judge. Either the court must be able to justify placing complete faith in the registration committee (and the particular composition of the committee itself determined by yet another body of experts?) when it certifies evidence as a reliable basis for prosecution or excludes evidence that might be capable of raising a reasonable doubt; or it must - as C.A.J. Coady argues in his qualified endorsement of Kenny's proposal - be prepared to entertain challenges to the Committee's view. ${ }^{57}$ The latter course raises precisely the difficulty of deciding between rival groups of experts that Kenny's proposal was designed to avoid. As Brewer argues, there is no escape from the need for the tribunal of fact to be able to justify its reliance on, or rejection of, expert testimony. In the remainder of the article, I argue that this is not such an impossible task as Brewer supposes.

52 See Golanski, op. cit., n. 50 and pp. 582-6 below.

53 See S.R. Gross, 'Expert Evidence' (1991) Wisconsin Law Rev. 1193.

54 Brewer, op. cit., n. 18, p. 1668.

55 A. Kenny, 'The Expert in Court' in The Ivory Tower: Essays in Philosophy and Public Policy (1985).

$56<\mathrm{http}: / /$ www.crfp.org.uk/> (accessed 25 July 2006); Science and Technology Committee, op. cit., n. 47, paras. 132-9; Roberts and Ormerod, op. cit., n. 45.

57 Coady, op. cit., n. 9, pp. 288-9. 
The first step in seeing how lay people can decide whether to believe experts is, I suggest, to distinguish between three different forms that the expert/ layperson relationship can take, depending on the way in which the layperson regards the inferences drawn by the expert.

First, the layperson may treat the expert as a source of factual information but disregard - or in the legal context, treat as inadmissible - any inferences the expert draws from that information (either generally or in respect of particular matters). Courts were formerly required (in theory) to take this view in respect of the so-called 'ultimate issue', but this rule has now been abolished in civil proceedings and abandoned in criminal cases. ${ }^{58}$ An expert whose inferences are disregarded entirely is not an expert in the legal sense, but simply a witness of fact.

Secondly, the layperson may take the inferences drawn by the expert as potentially persuasive arguments to be considered on their merits. In this situation the layperson considers herself able to understand the expert's reasoning, to weigh it with any other evidence that supports or refutes it, and decide whether to accept or reject it. The fact that the expert draws on a special body of knowledge or experience may add weight to his reasoning, but does not preclude the layperson from evaluating it independently.

Thirdly, the layperson may feel unable to understand or evaluate the expert's reasoning but may have reasons for believing that whatever conclusion the expert comes to is probably based on good reasons. ${ }^{59}$ The expert's inferences are treated as authoritative, in the sense explained by H.L.A. Hart:

the reason for belief constituted by a scientific authority's statement is in a sense peremptory since it is accepted as a reason for belief without independent investigation or assessment of the truth of what is stated. It is also content-independent since its status as a reason is not dependent on the meaning of what is asserted so long as it falls within the area of his special expertise. $^{60}$

As Hart goes on to point out, calling someone an 'authority' on some subject implies that there is some good reason to believe that what she says about that subject is likely to be true.

An examination of the recent cases applying the Bonython test suggests that the courts do implicitly distinguish between factual, persuasive, and authoritative testimony, and that in some cases they give careful consideration to the factors that justify accepting evidence of the relevant type as reliable.

58 Civil Evidence Act 1972, s. 3; Re M. \& R. [1996] 4 All E.R. 239; R. v. Stockwell (1993) 97 CAR 260, 265-6; $R$ v. Ugoh [2001] EWCA Crim 1381 [19].

59 J. Hardwig, 'Epistemic Dependence' (1985) 82 J. of Philosophy 835.

60 H.L.A. Hart, 'Commands and Authoritative Reasons' in Essays on Bentham (1982) 261. 


\section{Factual testimony and generalizations from experience}

$R$ v. Meads ${ }^{61}$ appears to be the first English criminal appeal in which the Bonython test was cited. The appellants, who had been convicted partly on the basis of confession evidence, sought to introduce new expert evidence which compared the speeds at which experimental subjects were able to write by hand with the speeds at which certain police officers would have had to write to make the notes of the alleged confession within the time that they claimed to have made them. In seeking to exclude this evidence, the Crown relied on question 1(b) of the Bonython test, ${ }^{62}$ arguing that such small-scale ad hoc experiments did not amount to a 'sufficiently organised body of knowledge or experience' to be reliable. ${ }^{63}$ The Court of Appeal rejected this submission on the ground that 'any inference to be derived from this relatively limited experimental data the jury could easily derive for themselves without expert assistance'; thus it was not opinion evidence but evidence of fact and Bonython did not apply. Had the experts been available at trial, their testimony would have been admissible as to their results but not as to their opinions based on those results.

There are obvious difficulties in attempting to draw a clear line between 'fact' and 'opinion' ${ }^{64}$ Had the handwriting experts testified at trial, the prosecution would probably have wanted to cross-examine them about the same issues that they raised during the appeal; for example, vagaries in the calculation of writing speeds and the possibility that police officers might be speedier note-takers than psychology students. The experts could hardly have answered these questions without, at least implicitly, advising the jury as to what inferences could be drawn from their data as to police officers' writing speeds. Such opinions are, however, quite the opposite of Hart's 'content-independent and peremptory' scientific statements; the reasons for believing them are entirely content-dependent and open to critical evaluation by the jury. Because of the transparency of the experts' reasoning, there was relatively little need for additional reasons to believe that their inferences were reliable. Rather than distinguishing Bonython, the Court might have done better to apply it by saying that the experiments constituted a 'body of experience' that was 'sufficiently organised' to justify a limited degree of reliance by the jury.

In cases like Meads, the putative expert draws a generalization from a body of experience (in our experiments no-one could write faster than 155 characters a minute), and leaves the jury to draw its own inferences in relation to the facts of the specific case (either these officers are lying or they can write exceptionally fast). Is such a generalization (whether based on

61 Meads [1996] Crim. L.R. 519.

62 (1984) 38 SASR 45.

$63 R$ v. Meads, Lexis transcript, 26 January 1996.

64 Roberts and Zuckerman, op. cit., n. 33, pp. 143-6. 
methodical observation or simply long experience of a particular occupation) an expert inference, or merely a way of summarizing a set of facts? ${ }^{65} \mathrm{~A}$ similar ambiguity arises when police officers or drugs charity workers testify about patterns of drug use and dealing. Such evidence has been categorized in three different ways by the Court of Appeal: as inadmissible opinion evidence, ${ }^{66}$ as admissible "evidence of fact of what takes place on many occasions on the streets' ${ }^{67}$ and most recently, in two judgments purporting to apply Bonython, as admissible expert evidence. ${ }^{68}$

The latest decision is $R$ v. Ibrahima, where the Court stated that experience (in this case, as the Deputy Director of the charity Release) could be a basis for expertise and that neither formal qualifications nor 'a rigorously scientific basis' were required to render the evidence admissible. ${ }^{69}$ In principle this must be correct. Bonython (unlike Clark v. Ryan, ${ }^{70}$ which introduced the 'organized body of knowledge' test in Australian law) accepts that not only 'organized knowledge' but also 'recognized experience' can constitute expertise. While formal qualifications are one form of 'recognition', most professionals will have acquired the bulk of their experience after they gained whatever formal credentials they possess, and valuable experience is not confined to the learned professions; ${ }^{71}$ Aboriginal trackers, for example, have been held to meet the Bonython 'recognized experience' test. $^{72}$ There are, however, legitimate concerns about the impartiality of 'experts' like that in Hodges, whose claim to recognized expertise rests solely their experience as members of the investigating police force. ${ }^{73}$

\section{Persuasive testimony}

In $R$ v. Dudley, ${ }^{74}$ the defendant in a murder case proposed to call an accident reconstruction expert to support his defence that he had not deliberately

65 For a meticulous analysis, see D.M. Risinger, 'Preliminary Thoughts on a Functional Taxonomy of Expertise for the Post-Kumho World' (2000) 31 Seton Hall Law Rev. 508, at 511-16.

$66 R$ v. Edwards [2001] EWCA Crim 2185.

$67 R$ v. Bryan (unreported, 1984), quoted in $R$ v. Hodges (1983) 76 Cr. App. R. 48 [11]; $R$ v. Jeffries [1997] Crim. L.R. 819.

68 Hodges, id. Ibrahima [2005] EWCA Crim 1436.

69 Ibrahima, id., paras. 29-30.

70 Clark v. Ryan (1960) 103 C.L.R. 486; see Richard Eggleston's criticisms in Evidence, Proof and Probability (1978), 128-9.

71 id., citing among other examples Smith v. Cook [1875] 1 Q.B.D. 79, 82 ('people acquainted with marsh land' as experts on safe grazing of animals).

$72 R$ v. Harris (1997) 94 A. Crim. R. 454.

73 Hodges, op. cit., n. 67; R. Fortson, Misuse of Drugs and Drugs Trafficking Offences (2005, 5th edn.) s. 11083-84 (pp. 408-9). In $R$ v. Gokal (Lexis, 11 March 1999) the evidence of a chartered accounted seconded to the Serious Fraud Office was held admissible, but on the basis of his professional qualification, not his SFO experience.

74 Dudley [2004] All E.R. (D) 374 (Nov). 
driven his car at the deceased, but had been confused by the road layout. The expert's proposed evidence consisted of observations of the visibility of the relevant stretch of road under similar conditions to those at the time of the incident, and his inferences as to the confusion the view might have caused in the mind of the driver. The trial judge regarded this evidence as inadmissible under the 'common knowledge' rule ${ }^{75}$ because road conditions and their likely effect on motorists would be within the knowledge of the jury. Allowing the defendant's appeal, Pill LJ cited Bonython and held the expert's evidence admissible on the grounds that although the jury would have had experience of roads and their dangers, they would be better placed to make a sound judgment if they had the benefit of the expert's 'very great experience in investigating ... driver behaviour in relation to particular [road] configurations'. ${ }^{76}$

Dudley is a good example of the type of expert evidence to which the jury might reasonably show a degree of deference, but which is by no means authoritative in the sense of being a content-independent or peremptory reason for belief. The jury could assess the expert's conclusions in the light of the other evidence and those who were motorists ${ }^{77}$ could draw upon their own experiences, as well as considering how far the expert's generalizations in fact supported his conclusions. What the jury could not do was to reexamine every accident the expert had investigated and consider how far it supported his generalizations about driver confusion.

The jury is in a similar position when evaluating psychiatric or psychological evidence about past mental states. Jurors are presumably experienced in inferring people's mental states from their words and actions, and while the fact that an expert drawing on a different body of experience arrives at different inferences may lead them to reconsider their interpretations, it does not compel them to abandon their own sense of what is plausible. As Parker CJ put it in the leading case on diminished responsibility manslaughter:

medical evidence is no doubt of importance, but the jury are entitled to take into consideration all the evidence, including the acts or statements of the accused and his demeanour. They are not bound to accept the medical evidence if there is other material before them which, in their good judgment, conflicts with it and outweighs it. ${ }^{78}$

The danger of admitting such evidence is that the fact-finder will give it more than the limited deference it deserves and, in effect, delegate to a partisan witness a task that ought to be carried out by the jury or judge. For

75 Turner, op. cit., n. 43.

76 Dudley, op. cit., n. 74, para. 32.

77 With 70 per cent of eligible residents in England and Wales holding driving licences $(<$ http://www.statistics.gov.uk/cci/nugget.asp?id=1093 $>$ ), the odds against a motorist-free jury are astronomical.

$78 R$ v. Byrne [1960] 2 Q.B. 396, 403. See, also, $R$ v. Sanders [1991] 93 Cr. App. R. 245 . 
example, the trial judge in Liddell v. Middleton adopted verbatim the conclusions of the accident reconstruction expert called by the plaintiff, to the effect that a driver who ran down a pedestrian was 'grossly negligent'. ${ }^{79}$ While he may simply have found the expert's arguments persuasive, just he might have found counsel's arguments persuasive, the impression was given that he had illegitimately deferred to an expert on a matter that he was required to judge for himself on the basis of the testimony he had heard. The Court of Appeal held the evidence inadmissible. In other civil cases, the Bonython test has been used to exclude expert evidence on issues of negligence or breach of duty unless (a) the judge cannot form a judgment without expert help and (b) there is an 'objectively ascertainable standard or consensus within a recognized profession' to which the witness is qualified to testify. ${ }^{80}$

The so-called 'common knowledge rule' (restated as limb (a) of the first question in Bonython) can be interpreted as one manifestation of the principle that evidence should be excluded if its potential prejudicial effect exceeds its probative value. ${ }^{81}$ What gives rise to the prejudicial effect is the risk that the jury will treat the expert evidence as authoritative rather than merely persuasive, because treating expert evidence as authoritative saves time and effort:

Low value expert testimony can distort the fact-finding process by taking a relatively simple issue, dressing it up in scientific language and presenting the trier of fact with a ready-made decision. The jury may be tempted to avoid engaging in serious consideration of the actual facts and instead rely on the apparent expertise of the scientist. In effect, the expert may usurp the domain of the jury. Trial judges must take this possibility into account in determining whether the prejudicial effect of expert evidence outweighs its probative value. ${ }^{82}$

While the risk of excessive deference to this kind of evidence is a reason for caution in admitting it, the fact that a relatively low degree of deference is required is also a reason for not setting the threshold of admissibility too high. As Christopher Slobogin argues in the American context, it cannot possibly be demonstrated that psychiatrists can accurately identify past mental states, but that does not mean that their evidence is too unreliable to be admitted. ${ }^{83}$ Psychiatrists are not reliable authorities on past mental states,

79 Liddell v. Middleton [1996] P.I.Q.R. P36, 40-41.

80 The Hellespont Ardent [1997] 2 Lloyd's Rep. 547, 598; see, also, Barings p.l.c. v. Coopers \& Lybrand [2001] Lloyd's Rep. Bank. 85, paras. 37-8.

81 P. Roberts, 'Will You Stand Up In Court? On The Admissibility of Psychiatric and Psychological Evidence' (1996) 7 J. of Forensic Psychiatry 63. See Roberts and Ormerod, op. cit., n. 45, ss. 24.16-24.32 for an excellent overview of the present law on 'common knowledge'.

$82 R$ v. $D$ (2000) 191 D.L.R. (4th) 60, per McLachlin CJC, para. 39 (dissenting as to how this principle should be applied to the facts).

83 C. Slobogin, 'Psychiatric Evidence in Criminal Trials: To Junk or Not to Junk?' (1998) 40 William \& Mary Law Rev. 1. 
but they can interpret events in ways which juries may reasonably rely upon to the extent that they find them insightful and persuasive.

\section{Authoritative testimony}

An expert has legitimate cognitive authority - authority that a layperson can rationally accept - if there are good reasons to believe that what she asserts is likely to reflect the balance of reasons for and against believing it, and if lay people have good reasons for refraining from independent consideration of the expert's reasons. ${ }^{84}$ In some cases, for example, handwriting analysis, English juries are expressly told not to make their own assessment of the issue on which the expert testifies. ${ }^{85}$

A paradigm case of legitimate cognitive authority is that of physics:

We all know or have testimony that comes from users or recipients about the efficacy of the products of physics, such as nuclear weapons, which we accept. We are told that these results derive from the principles of physics, from the 'knowledge' that physicists certify one another as possessing. Consequently we have grounds for accepting the claim of physicists to cognitive authority, and in this sense our 'faith' in physics is not dependent on faith alone. Of relevance is the fact that these are not wholly the grounds that physicists themselves rely on in accepting one another's cognitive claims. ${ }^{86}$

The authority of physicists, then, rests both on a track record of demonstrably accurate statements about, and effective interventions in, the domain in which they claim expertise, and on a consensus within the expert community about the principles underlying those achievements. Some forms of expertise rely on one or other of these two grounds of legitimation, some on both. While assessing these reasons for belief is not easy and can lead lay people (including judges) astray, it does not require any kind of specialist knowledge.

(a) Authority based on track record

As Goldman argues, one of the most important ways in which lay people can recognize experts as reliable without falling back on 'blind trust' is by becoming aware of their track records of making statements that have proved to be accurate. ${ }^{87}$ A layperson who cannot understand the experts' reasons for their conclusions can infer, from the fact that the experts' conclusions, or

84 As Raz observes, there is a close parallel in this respect between cognitive and political authority: J. Raz, The Authority of Law (1979) 20-1; 'Authority and Justification' in Authority, ed. J. Raz (1990) 128-9.

$85 R$ v. O'Sullivan [1969] 1 W.L.R. 497; Judicial Studies Board Specimen Direction 33, <http://www.jsboard.co.uk/criminal_law/cbb/mf_04b.htm\#33> (accessed 28 March 2006).

86 S.P. Turner, Liberal Democracy 3.0: Civil Society in an Age of Experts (2003) 25.

87 Goldman, op. cit., n. 24, pp. 268-71; Goldman, op. cit., n. 9, pp. 106-8. 
conclusions reached by applying the techniques they have used, have repeatedly been proved right, that they were probably based on good reasons. Judges, unfortunately, do not have a good track record of making such inferences.

Several leading decisions rest on an elementary fallacy, epitomized by Vaughan Williams J's intervention during the argument in $R$ v. Silverlock: 'No one should be allowed to give evidence as an expert unless his profession or course of study gives him more opportunity of judging than other people. ${ }^{88}$ The mere fact that a person has more opportunities of judging than others does nothing to prove that his judgements are correct. People can learn to make accurate judgements through practice, but only if they receive reliable feedback as to whether their judgements are accurate. ${ }^{89}$ The court's ready acceptance in Silverlock that a solicitor who made a hobby of comparing manuscripts was 'peritus' (skilled) might be explained historically as a product of the late nineteenth century's fascination with the ability of experts to interpret minute phenomena, ${ }^{90}$ but more recent cases such as $R$ v. $R_{o b b}{ }^{91}$ (dealing with comparison between voices), $R$ v. Dallagher ${ }^{92}$ (on 'earprints'), and a leading American case on forensic handwriting expertise, US v. Starzecpyzel, ${ }^{93}$ make the same mistake of supposing that experience of making judgements is in itself evidence of reliability.

A more careful approach was taken by the Court of Appeal in $R \mathrm{v}$. Luttrell, ${ }^{94}$ dealing with appeals from two trials in which forensic lip-reading evidence had been admitted. Endorsing the Bonython test which both trial judges had applied, the Court examined the expert evidence tendered by the defence and concluded 'that the best speech readers, of whom [the prosecution expert] is undoubtedly one, can achieve correctness of 80 per cent, or higher on repetition of videoed sequences'. ${ }^{95}$ This was sufficient 'recognition' to render the evidence admissible: the fact that its reliability was 'significantly short of perfection' was a matter of weight for the jury, but one

88 Silverlock [1894] 2 Q.B. 766, 769.

89 R.M. Dawes, House of Cards: Psychology and Psychotherapy Built on Myth (1994) ch. 4; M.P. Denbeaux and M.R. Rissinger, 'Kumho Tire and Expert Reliability: How the Question You Ask Gives the Answer You Get' (2003) 34 Seton Hall Law Rev. 15 , at 58 .

90 J.L. Mnookin, 'Scripting Expertise: The History of Handwriting Identification Evidence and the Judicial Construction of Reliability' (2001) 87 Virginia Law Rev. 1723 , at 1810 .

$91 R o b b$, op. cit., n. 37. In $R$ v. O'Doherty [2003] 1 Cr. App. R. 5, the Northern Ireland Court of Appeal held that the type of evidence relied on in Robb should no longer be admitted; see Ormerod, op. cit., n. 37.

92 Dallagher, op. cit., n. 38.

93 Starzecpyzel, 880 F. Supp. 1027 (S.D.N.Y. 1995) 1041, criticized by M. J. Saks, 'Merlin and Solomon: Lessons from the Law's Formative Encounters with Forensic Identification Science' (1998) 49 Hastings Law J. 1069, at 1097-8.

94 Luttrell, op. cit., n. 2.

95 id., para. 31. 
on which the judge must give careful guidance, pointing out the limitations of the evidence. ${ }^{96}$ The guidance required was analogous to the 'special warning' given in cases of eyewitness identification evidence. ${ }^{97}$ The Court of Appeal held that the judge in one trial had given sufficient warning and the other had not.

The evidence in Luttrell put the jury in a good position to assess the reliability of the lip-readers' evidence. ${ }^{98}$ Indeed the jury was arguably better equipped to make this assessment than the prosecution's lip-reader herself, who expressed levels of confidence beyond what the tests of her abilities seemed to justify. ${ }^{99}$ At the same time, Luttrell illustrates why inferring the reliability of an expert from her track record is by no means a straightforward exercise. The validity of the inference depends upon the similarity of the task undertaken on the present occasion to the task at which the expert's past performance is known, and the similarities and differences between those tasks may themselves be the subject of conflicting expert opinion. For example, the prosecution lip-reader and one of the defence experts disagreed over whether the video in the Luttrell trial was easier or harder to read than that on which the defence expert had tested the lip-reader some years earlier, and whether improvements in the lip-reader's transcription techniques since that test would have led to a better result. ${ }^{100}$ The Court of Appeal acknowledged that judges would need to make 'highly fact sensitive judgments' about the skills of particular lip-readers and the readability of particular videos. ${ }^{101}$ This reflects the personal nature of lipreading skills; in other cases it will be the track record of a technique, rather than an individual expert, that is chiefly important.

\section{(b) Authority based on consensus and/or critical scrutiny}

The second reason for according legitimate cognitive authority to a group of experts is that there is a consensus among them which is best explained by their possessing good reasons for their shared belief. W.K. Clifford illustrates this argument in his classic essay, 'The Ethics of Belief', explaining why a layperson can justifiably accept certain information on the authority of a chemist:

His result, the belief to which he has been led by his inquiries, is valid not only for himself but for others; it is watched and tested by those who are working in the same ground, and who know that no greater service can be rendered to science than the purification of accepted results from the errors which may

96 id., paras. 31, 36, 44 .

97 id., paras. $41-4$.

98 It is now known that the evidence of her qualifications was inaccurate in one respect (see n. 34 above) but her supposed degree was not a qualification in lip-reading.

99 Luttrell, op. cit., n. 2, para. 31.

100 id., paras. 13, 15.

101 id., para. 38. 
have crept into them. It is in this way that the result becomes common property, a right object of belief, which is a social affair and matter of public business. $^{102}$

This argument rests on some large assumptions about the character of chemists and their scholarly community: ${ }^{103}$ that they are independent of one another, freely criticize one another's work, and are motivated by a disinterested pursuit of truth. To expect similar characteristics of expert witnesses may appear to be a sign of judicial naivety about the social nature of scientific inquiry. ${ }^{104}$ Gary Edmond, in an important article advocating a constructivist view of scientific evidence, ${ }^{105}$ argues that judges expect scientists to conform to norms resembling those described by the sociologist Robert Merton, whereas subsequent sociological research has suggested that such norms, though important to science's public image, are honoured largely in the breach by working scientists. From the layperson's perspective, however, Merton's norms can be understood as general principles of rational discourse which must be followed if science is to claim legitimate cognitive authority. ${ }^{106}$ The norms of 'universalism' and 'disinterestedness' express the ideas that anyone may participate in discourse on an equal footing regardless of their personal status, and should engage sincerely in a search for truth. ${ }^{107}$ The other two norms, 'communism' and 'organized scepticism', embody the idea that no proposition is 'off limits' for any participant in the discourse, either because it is a particular scientist's 'property' or because it is 'sacred'. ${ }^{108}$ These are close to the key norms of Habermas's and Alexy's 'discourse ethics', rules that encapsulate the structure of 'cooperative competition for the better argument'. ${ }^{109}$ The more closely a discourse approximates to those norms, the more likely it is that 'the unforced force of the better argument ${ }^{110}$ will prevail, and thus the more likely it is that a layperson who treats a consensus arrived at by such a discourse as an authoritative reason for belief will adopt beliefs based on good reasons. If scientists persistently flout Mertonian norms, therefore, this raises serious questions about the legitimacy of their cognitive authority -

102 W.K. Clifford, Lectures and Essays (1879) vol. 2, 197.

103 For a less flattering picture of Victorian chemistry, see T. Golan, Laws of Men and Laws of Nature: The History of Scientific Expert Testimony in England and America (2004) 54-106.

104 See, for example, B. Wynne, Rationality and Ritual: The Windscale Inquiry and Nuclear Decisions in Britain (1982) ch. 7; Jones, op. cit., n. 6.

105 Edmond, op. cit, n. 6, pp. 220-4.

106 R.K. Merton, 'The Normative Structure of Science', reprinted as ch. 13 in Sociology of Science, ed. N.W. Storer (1973).

107 id., pp. 270-2, 275-7.

108 id., pp. $275,277-8$.

109 J. Habermas, The Inclusion of the Other (1998) 44. See, also, R. Alexy, A Theory of Legal Argumentation (1989) 193-4.

110 Habermas, id., p. 37. 
which partly explains why sociologists who reject the Mertonian view of science provoke such heated controversy. ${ }^{111}$

But how can lay people - by definition, non-participants in the relevant expert discourse - possibly tell whether these ideals of rationality have been complied with? Judges and juries can often discern that the norms have not been complied with, since adversarial procedure can be very effective in 'deconstructing' scientific and other forms of expert authority, 'making transparent the values, biases and social assumptions that are embedded in many scientific claims about social and natural phenomena'. ${ }^{112}$ Ironically, the adversarial system also tends to produce the very appearance of bias that it then proceeds to expose. ${ }^{113}$ Yet such deconstruction does not necessarily lead courts to reject expert evidence, rather than to 'reconstruct' its authority as a basis for decision. ${ }^{114}$ In other words, one can generally find reasons for scepticism about expert authority if one looks hard enough, but such reasons do not always prevail over the reasons for belief. Belief in expert testimony, like belief in other forms of testimony, is underdetermined by reason; but that does not entail that it is irrational or arbitrary.

As Clifford's argument implies, the best ground for deferring to a consensus among experts is that one has reason to believe that the consensus is the outcome of rigorous critical scrutiny and debate. In United States law, the Frye ${ }^{115}$ test posits the 'general acceptance' of the principles underlying an expert's evidence 'in the particular field in which it belongs' as the criterion of admissibility, but does not stipulate how that acceptance must be achieved.

In Mallard v. The Queen, ${ }^{116}$ the Western Australia Supreme Court combined Bonython with a modified version of Frye: the proponent of a 'novel' theory or technique must show that it is 'accepted as reliable among impartial and disinterested experts within the scientific community'.117 Polygraphy was not sufficiently accepted among psychologists or psychophysiologists who did not have a vested interest in its acceptance to 'constitute part of a body of knowledge or experience which is sufficiently recognised to be accepted as a reliable body of knowledge or experience. ${ }^{118}$ The reference to 'impartial and disinterested experts' could be seen as

111 See, for example, P.R. Gross and N. Levitt, Higher Superstition: The Academic Left and its Quarrels with Science (1997).

112 Jasanoff, op. cit, n. 6, p. 20.

113 Golan, op. cit., n. 103; Gross, op. cit., n. 53, pp. 1165-76; New South Wales Law Reform Commission, Report 109: Expert Witnesses (2005) paras. 5.5-5.20.

114 B. Wynne, 'Establishing the Rules of Laws: Constructing Expert Authority' in Expert Evidence: Interpreting Science in the Law, eds. R. Smith and B. Wynne (1989) 37.

115 Frye, op. cit., n. 44.

116 [2003] WASCA 296 (reversed on other grounds [2005] HCA 68).

117 id., para. 288, quoting Kluck v. Borland 413 NW 2d 90 (1984).

118 id., para. 355 . 
another piece of judicial naivety, since all statements by experts are in some way linked to their professional goals and interests. But this sociological point does not negate the distinction between relatively disinterested experts and those to whose evidence courts can 'apply Rice-Davies' law and conclude: well, he would wouldn't he'. ${ }^{119}$

In Daubert v. Merrell Dow Pharmaceuticals (also cited in Mallard) the Supreme Court decided that general acceptance or the lack of it was relevant but not decisive and that federal judges should take account of three additional criteria: 'whether a theory or technique ... can be (and has been) tested'; whether it has been subjected to peer review and publication; and 'the known or potential rate of error'. ${ }^{120}$ Rehnquist CJ's dissenting judgment forcefully criticized these criteria for requiring lay judges 'to become amateur scientists ${ }^{121}$ and, like many academic commentators, derided the majority's reliance on Popper's concept of falsifiability. ${ }^{122}$ Whatever its standing in the philosophy of science, falsifiability is not a helpful criterion for the lay person. 'From the point of view of practical life', as Popper himself puts it, the scientific theories we have most reason to rely on are simply those that have been most extensively 'discussed, criticised, and tested' ${ }^{123}$ Whether a theory has withstood critical discussion and testing, not whether it is falsifiable in principle, is the question a layperson needs to ask before deciding that a body of knowledge can safely be treated as authoritative. ${ }^{124}$ With that amendment, the first two Daubert criteria (testing and peer review) are reasonable indications that the theory or technique has been subjected to critical scrutiny, while the third (error rate) takes account of a technique's track record of generating accurate results.

The drawback of Daubert - and more particularly of its extension to nonscientific expertise in Kumho Tire v. Carmichael ${ }^{125}-$ is its failure to recognize that some forms of expertise can be helpful to fact-finders although they

119 B. Barnes, D. Bloor, and J. Henry, Scientific Knowledge: A Sociological Analysis (1996) 123. The NSW Law Reform Commission, op. cit., n. 113, para. 5.3, accepts Edmond's argument (op. cit., n. 6) that no expert is entirely 'objective', but distinguishes the 'universal phenomenon' of expert 'preconceptions' from the problem it defines as 'adversarial bias'.

120 Daubert, op. cit., n. 3, pp. 593-4.

121 id., p. 601.

122 id., p. 600; K.R. Popper, Conjectures and Refutations (1989, 5th edn.) 37, cited in id., p. 593. For critical commentary see, for example, Jasanoff, op. cit., n. 6, p. 63; G. Edmond and D. Mercer, 'Conjectures and Exhumations: Citations of History, Philosophy and Sociology of Science in US Federal Courts' (2002) 14 Law \& Literature 309; S. Haack, 'Truth and Justice, Inquiry and Advocacy, Science and Law' (2004) 17 Ratio Juris 15, 21-2.

123 K.R. Popper, Objective Knowledge (1979, rev. edn.) 80.

124 See M. Redmayne, Expert Evidence and Criminal Justice (2001) 113-16; D.H. Kaye, 'On "Falsification" and "Falsifiabililty": The First Daubert Factor and the Philosophy of Science' (2005) 45 Jurimetrics J. 473.

125 Kumho Tire, op. cit., n. 3. 
do not merit being treated as authoritative. Daubert and Kumho therefore create problems if applied rigidly to such unscientific and non-authoritative forms of expertise as psychiatric interpretations of past mental states. ${ }^{126}$

\section{CONFLICTING EXPERTS}

This article has dealt mainly with the decisions whether to admit and whether to believe a single expert. It may appear that even if these questions can be resolved, the problem of how to resolve conflicts of expert testimony remains intractable. ${ }^{127}$ There is not space to consider this problem in detail here, but a few brief observations are in order.

When dealing with non-authoritative evidence there is, in principle, no problem. If the jury in a diminished responsibility case, for example, is capable of judging the plausibility of a single psychiatrist's interpretation of events, they are equally capable of weighing the relative plausibility of two different accounts on the balance of probabilities (which is the standard the defence, on whom the onus of proof rests, has to meet). ${ }^{128}$ Moreover, whether evidence is treated as authoritative depends largely on the time and effort the fact-finder is willing to invest in reaching an independent understanding of the arguments. Judges who have to give reasoned judgments in complex civil disputes can develop sufficient knowledge of the competing arguments to judge which is more probable from the standpoint of the informed layperson - a judgment which may be largely a matter of narrative plausibility. ${ }^{129}$ Moreover, the manner in which experts defend their positions under cross-examination may provide a number of grounds to make reasoned judgments of credibility. ${ }^{130}$

One example of such a reasoned judgment is provided by the very aspect of the much-cited ${ }^{131}$ Ikarian Reefer litigation which Edmond uses to illustrate judges' flexible use of Mertonian norms ${ }^{132}$ - namely, the different interpretations which the trial judge and the Court of Appeal placed on the willingness of a particular metallurgist to change his mind in the light of another expert's report. ${ }^{133}$ It is a reasonable 'heuristic' or rule-of-thumb for a

126 C. Slobogin, 'Doubts about Daubert: The case of Psychiatric Anecdata' (2000) 57 Washington and Lee Law Rev. 919.

127 Brewer, op. cit., n. 18.

$128 R$ v. Lambert, Ali and Jordan [2002] Q.B. 1112, 1118-19.

129 See T. Ward, 'Law's Truth, Lay Truth and Medical Science: Three Case Studies' in Law and Science, ed. H. Reece (1998).

130 Goldman, op. cit., n. 9; D. Matheson, 'Conflicting Experts and Dialectical Performance: Adjudication Heuristics for the Layperson' (2005) 19 Argumentation 145.

131 As a source of guidance on the duties of expert witnesses: see, for example, $R \mathrm{v}$. Harris, op. cit., n. 2; $R$ v. $B(T)$ [2006] 2 Cr. App. R. 3, para. 177.

132 Edmond, op. cit., n. 6, pp. 222-4.

133 National Justice Compania Naviera SA v. Prudential Assurance Co Ltd (The "Ikarian Reefer") [1993] 2 Lloyd's Rep. 68 (Q.B.), [1995] 1 Lloyd's Rep. 455 (C.A.). 
layperson to regard an expert's willingness to take account of new information or arguments as an indication of open-mindedness - a disposition to heed all relevant reasons whether or not they support a preconceived view. ${ }^{134}$ Ceteris paribus, this is an indication that the expert is likely to be a reliable guide to the balance of reasons for and against a given belief. But if the expert changes his mind in the light of reasons that he ought to have considered in the first place, this is an indication of carelessness or bias in forming his initial opinion. The metallurgist might have given this impression to the trial judge since he conceded that he 'didn't consider [the interpretation of certain photographs] as carefully as I should have done in terms of a different ... theory'. ${ }^{135}$ The Court of Appeal considered that in view of the difficulty of interpreting the photographs, the metallurgist was 'not to be criticised for thinking that he might have been mistaken' and he had not been shown to be biased or inflexible. ${ }^{136}$ While these two passages can no doubt be described as examples of the social de- and reconstruction of scientific authority, they are also cogent pieces of lay reasoning about expert testimony. ${ }^{137}$

Recent controversies about infant deaths have forced the Court of Appeal to consider carefully the position where complex and conflicting expert testimony is presented in criminal cases. In principle the position seems clear. Where a conflict between two 'reputable' experts is determinative of the case, it will normally be unsafe to convict. ${ }^{138}$ In other cases, the jury by taking a holistic view of both the expert and the lay evidence may be able to conclude that the prosecution account of events is overwhelmingly more probable. ${ }^{139}$

The Cannings case does, however, reveal a serious anomaly arising from the Galbraith test as to when a case should be left to the jury. A prosecution case which depends on contested expert evidence may well be one where 'the prosecution evidence, taken at its highest' is such that a jury could properly convict upon it - the test for whether there is a case to answer ${ }^{140}$ but there may be no rational basis on which the jury could confidently prefer the prosecution evidence to the defence evidence. This should be a ground for withdrawing the case from the jury, but dicta in Cannings indicate that it is not. ${ }^{141}$

134 Matheson, op. cit., n. 130, pp. 151-2.

135 Quoted in Ikarian Reefer, op. cit. (Q.B.), n. 133, p. 106.

136 id. (C.A.) 496.

137 That sociological and normative analyses of knowledge are not mutually exclusive is stressed by H.E. Longino, The Fate of Knowledge (2002).

$138 R$ v. Cannings [2004] 1 All E.R. 725, para. 178; $R$ v. Harris [2005] 85 BMLR 75, paras. 119, 144-5, 195; $R$ v. Puaca [2005] EWCA Crim 3001, paras. 64-5.

139 Cannings, id., paras. 172-80; $R$ v. Kai-Whitewind [2005] 2 Cr. App. R. 31 - a decision which though sound in principle is troubling on its facts: see C.P. Walker, 'Commentary' [2006] Crim. L.R. 350.

$140 R$ v. Galbraith (1981) 73 Cr. App. R. 124, 127.

141 Cannings, op. cit., n. 138, para. 163. 
The Bonython test distinguishes between two types of expertise - 'knowledge' and 'experience' - and two grounds for accepting expert evidence as reliable: 'organization' and 'recognition'. In the light of the above discussion, these distinctions can be interpreted as follows. 'Experience' may consist simply of observations, or of generalizations drawn from observations or from prolonged familiarity with particular subject-matter. Experiential expertise may be reliable either because it is 'organized', that is, acquired and recorded in a systematic manner, like the timings of handwriting in Meads; or because it is 'recognized', for example, where the witness belongs to some established profession or occupation dealing with the relevant phenomena. 'Knowledge' can be subdivided into 'knowing how' (to lip-read for example) and 'knowing that'. ${ }^{142}$ The former is often incapable of being fully articulated ${ }^{143}$ and the latter may be very complex; thus, both may be difficult to evaluate independently and may best be treated as authoritative. The layperson may rationally treat (purported) knowledge as authoritative because it is recognized as having a track record of yielding demonstrably correct propositions, or because it is organized as a cumulative body of knowledge built up through critical scrutiny, empirical testing, and debate. While the criterion of 'recognition' will often be particularly relevant to 'know-how' (as in Luttrell), and 'organization' to propositional knowledge, some forms of knowledge (for example, physics and DNA identification techniques) can lay claim to both. What it means for knowledge or experience to be 'sufficiently organized or recognized' to be relied upon depends upon the kind of reliance the fact-finder is invited to place on it. Evidence which, if accepted at all, can only be treated as authoritative requires a more rigorous standard than evidence that can be treated as merely persuasive. Before admitting the latter kind of evidence, however, criminal courts should (in considering the 'common knowledge' limb of Bonython) weigh its probative value against the risk that a jury may accord it an authority it does not deserve.

Interpreting Bonython in this way would furnish English law with a coherent epistemology which rejects the 'incredibly liberal' ${ }^{144}$ stance taken in cases like Robb and Dallagher, while preserving the principle that the decision whether to believe purported experts rests not with other experts but with the lay representatives of the community.

142 G. Ryle, The Concept of Mind (1949) ch. 2.

143 M. Polanyi, Personal Knowledge (1958) 88-91.

144 Ormerod, op. cit., n. 37, p. 777. 